\title{
PENGARUH CITRA PERUSAHAAN DAN KUALITAS LAYANAN TERHADAP KEPUASAN ANGGOTA KOSPIN JASA
}

\author{
Alfian Wijanarko ${ }^{1)}$ \\ 1) Mahasiswa Program Studi Manajemen FE UNKRIS \\ Devi Krisnawati ${ }^{2)}$ \\ 2) Dosen Program Studi Manajemen FE UNKRIS \\ Alamat: Kampus UNKRIS, Jatiwaringin Jakarta Timur \\ Email: devikrisnawati@gmail.com
}

\begin{abstract}
To determine the effect of company image and service quality on member satisfaction Kospin Jasa. The research method uses qualitative and quantitative descriptive analysis, the analysis model used is linear regression both simply and multiple. The study population was all 116 members of the Kospin Jasa. The sampling technique of this study used simple random sampling. This study uses a sample size with the Slovin formula and obtained as many as 55 respondents. Result the of company image and service quality have a positive and significant effect on satisfaction of Kospin Jasa members both partially and simultaneous.
\end{abstract}

Keywords: Company image, service quality and member satisfaction

\section{PENDAHULUAN}

Kondisi Indonesia saat ini dinilai mengalami penurunan dalam hal pembangunan. Hal ini terlihat pada faktor menurunnya nilai tukar rupiah terhadap dolar AS. Maka kiranya perlu dilakukan pengembangan pembangunan nasional oleh Indonesia. Pembangunan nasional merupakan salah satu hal yang sedang diupayakan di Indonesia, terutama pembangunan ekonomi nasional. Pembangunan nasional adalah suatu upaya untuk meningkatkan seluruh aspek kehidupan masyarakat, bangsa, dan negara yang sekaligus merupakan proses pembangunan keseluruhan sistem penyelenggaraan negara untuk mewujudkan tujuan nasional. Pemerintah sudah melakukan berbagai upaya untuk memperbaiki dan mengembangkan pembangunan nasional di Indonesia. Koperasi merupakan salah satu bagian yang tidak dapat dipisahkan dari pembangunan nasional.

Bangsa Indonesia mempunyai tiga sektor kekuatan ekonomi yang melaksanakan berbagai kegiatan usaha dalam tata kehidupan perekonomian. Ketiga sektor tersebut adalah sektor pemerintah, swasta dan koperasi. Untuk mencapai kedudukan ekonomi yang kuat dan mencapai masyarakat yang adil dan makmur, maka ketiga sektor kekuatan ekonomi tersebut harus saling berhubungan dan bekerjasama secara baik.

Pasal 33 UUD 1945 menempatkan koperasi sebagai soko guru perekonomian nasional. Koperasi merupakan perkumpulan otonom dari orang-orang yang bergabung secara sukarela untuk memenuhi kebutuhan dan aspirasi ekonomi, sosial dan budaya mereka yang sama melalui perusahaan yang dimiliki dan diawasi secara demokratis, dengan tujuan untuk memajukan kesejahteraan anggota. Koperasi mempunyai peranan yang sangat penting dalam perekonomian nasional, karena tujuan dari koperasi adalah untuk meningkatkan kesejahteraan anggotanya. Jadi pada dasarnya koperasi merupakan tumpuan ekonomi Indonesia. Oleh sebab itu, koperasi perlu dibina secara profesional baik dalam bidang organisasi maupun dalam bidang mental dan usaha agar dapat maju dan berkembang. 
Melihat pentingnya koperasi, agar dapat berjalan dengan baik banyak hal penting yang sangat diperlukan dalam sebuah koperasi, misal pendidikan perkoperasian untuk pengurus dan anggota koperasi, motivasi berkoperasi anggota, citra koperasi yang baik, serta kualitas layanan yang baik. Jika semua faktor tersebut bisa terpenuhi oleh koperasi, maka anggota koperasi merasa puas dan akan berdampak dapat maju dan berkembangnya koperasi tersebut.

Kepuasan merupakan perasaan senang dan kelegaan anggota koperasi dikarenakan mendapatkan layanan jasa koperasi dengan baik. Kepuasan timbul akibat perasaan anggota koperasi setelah membandingkan hasil layanan dengan keinginannya terpenuhi.

Menurut Oliver (dalam Supranto, 2011) kepuasan sebagai "tingkat perasaan seseorang setelah membandingkan kinerja atau hasil yang dirasakannya dengan yang diharapkan". Apabila kinerja di bawah harapan, maka anggota akan sangat kecewa. Bila kinerja sesuai harapan, maka anggota akan merasa puas, sedangkan bila kinerja melebihi harapan, anggota akan sangat puas. Kepuasan anggota berarti bahwa kinerja suatu barang sekurang-kurangnya sama dengan apa yang diharapkan.

Untuk dapat maju dan terus berkembang, koperasi harus membuktikan bahwa koperasi tersebut dapat dipercaya. Citra adalah sesuatu yang sangat penting dalam sebuah badan usaha. Sekarang ini banyak sekali organisasi memahami sekali perlunya memberi perhatian yang cukup untuk membangun suatu citra yang menguntungkan bagi suatu perusahaan tidak hanya melepaskan diri terhadap terbentuknya suatu kesan publik negatif. Menurut Sukatendel dalam Soemirat dan Ardianto (2010) citra itu dengan sengaja perlu diciptakan agar bernilai positif. Citra itu sendiri merupakan salah satu aset terpenting dari suatu perusahaan atau organisasi Memiliki citra yang baik di mata masyarakat akan menjadi konsekuensi dari pembentukan citra. Citra dapat mendukung dan merusak nilai yang anggota rasakan. Citra yang baik akan mampu meningkatkan kesuksesan suatu koperasi. Istijanto, (2010) mengemukakan bahwa "perusahaan yang memiliki citra atau reputasi yang baik akan mempertinggi kemampuan bersaing, mendorong semangat kerja karyawan, dan meningkatkan loyalitas pelanggan". Kalau koperasi mempunyai citra yang baik maka koperasi dapat bersaing dan semangat kerja pengurus koperasi akan meningkat sehingga dapat meningkatkan kepuasan anggota. Begitu juga sebaliknya jika citra koperasi buruk maka akan berdampak negatif terhadap kepuasan anggota koperasi. Dengan melakukan penelitian citra, koperasi dapat mengetahui secara pasti sikap anggota terhadap koperasi maupun terhadap produk barang atau jasa yang dihasilkan oleh koperasi yang bersangkutan.

Dari penelitian citra ini, koperasi juga dapat mengetahui apa-apa yang disukai dan tidak disukai anggota tentang koperasi, dengan demikian koperasi dapat mengambil langkah-langkah yang tepat bagi kebijaksanaan koperasi selanjutnya (Danasaputra dalam Soemirat dan Ardianto, 2010).

Selain citra dalam mempertahankan pengguna jasa atau anggota agar memperoleh kepuasan yang tinggi, dibutuhkan strategi yang dapat diimplementasikan oleh pihak koperasi. Salah satu strategi yang paling penting dalam memenangkan hati pelanggan dalam hal ini anggota koperasi adalah dengan memberikan kualitas layanan prima. Kualitas layanan merupakan "upaya pemenuhan kebutuhan dan keinginan konsumen serta ketepatan penyampaiannya dalam mengimbangi harapan konsumen". (Tjiptono, 2015). Dalam tingkat persaingan yang semakin kompetitif ini, setiap koperasi menawarkan produk dengan fitur yang hampir sama, dengan demikian peningkatan kualitas layanan kepada anggota merupakan kunci sukses untuk mempertahankan anggota agar tidak berpindah ke koperasi lain atau untuk meningkatkan kepuasan anggota. Oleh karena itu kualitas layanan juga mempunyai hubungan yang sangat erat terhadap pertumbuhan 
koperasi yang bersangkutan. Kualitas layanan merupakan "alat penting untuk mengukur kepuasan pelanggan". (Hazlina et al, 2011). Apabila kualitas layanan baik maka kepuasan anggota dapat meningkat. Begitu juga sebaliknya bila kualitas layanan buruk maka akan berdampak negatif pada kepuasan anggota koperasi.

Koperasi Simpan Pinjam Jasa sejak berdiri telah menerapkan manajerial sistem. Rapat Anggota sebagai kekuasaan tertinggi memilih pengurus dan pengawas dari anggota untuk masa jabatan 5 tahun dengan formasi ketiga etnis yang ada. Pengurus bertindak sebagai policy maker dan pengawas operasional serta hal-hal yang berhubungan dengan segi organisasi koperasi. Dalam aktifitasnya beberapa pengurus ditunjuk sebagai supervisi sesuai dengan sistem operasional yang ada.

Operasional sehari-hari dikuasakan kepada Kepala Divisi, yang terdiri dari: Kepala Divisi Dana, Kepala Divisi Operasional, Kepala Divisi Pinjaman, Kepala Divisi Pengawasan \& Kepatuhan, Kepala Divisi Sistem \& Teknologi dan Kepala Divisi Treasury dan Bisnis dengan dibantu oleh Kepala Bagian Kantor Pusat dan Pimpinan Cabang beserta staf. Manajemen setiap bulan mengadakan rapat pleno untuk mengevaluasi kerja bulan sebelumnya dan menetapkan kebijakan-kebijakan yang akan ditempuh pada bulan mendatang. Sistem pengawasan intern dilakukan oleh Divisi Pengawasan yang dibantu oleh beberapa inspektur bidang, sedangkan di tingkat kantor cabang dibentuk Internal Control Unit (ICU).

Koperasi Simpan Pinjam Jasa adalah memberikan solusi dalam mengatasi kesulitan untuk mendapatkan pinjaman modal usaha mereka, karena umumnya bisnis mereka masih dikelola dengan cara tradisional. Menurut observasi yang dilakukan oleh peneliti, pendidikan perkoperasian hanya diberikan kepada pengurus saja sehingga pendidikan koperasi anggota masih sangat kurang. Setelah melakukan observasi dan wawancara peneliti memperoleh informasi bahwa citra yang ada pada koperasi masih kurang dipahami, baik disebabkan pernah ada pengurus yang tidak melaksanakan tugasnya dengan baik sehingga menyebabkan berkurangnya citra koperasi di mata anggota.

Untuk mengetahui Koperasi Simpan Pinjam Jasa dilakukan pembinaan untuk anggota dalam rapat anggota secara berkelanjutan dan bergantian di kantor cabang. Pembinaan usaha bagi anggota juga dilakukan melalui penerbitan direktori bisnis anggota Kospin Jasa, untuk mempromosikan produk usaha anggota kepada anggota lain dan mitra usaha. Dari hasil pembinaan diharapkan dapat meningkatkan kepuasan anggota dan akan memberikan dampak positif pada berkembang koperasi.

Tujuan penelitian ini adalah untuk mengetahui "pengaruh citra perusahaan dan kualitas layanan terhadap kepuasan anggota” (Studi pada Kospin Jasa).

\section{LANDASAN TEORI}

\section{Kepuasan}

Kepuasan adalah "perasaan senang atau kecewa seseorang yang muncul setelah membandingkan kinerja (hasil) produk yang dipikirkan terhadap kinerja (atau hasil) yang diharapkan". (Kotler, 2008). Menurur Oliver dalam Suprapto, (2011), kepuasan adalah sebagai tingkat perasaan seseorang setelah membandingkan kinerja atau hasil yang dirasakannya dengan harapannya. Apabila kinerja di bawah harapan, maka pelanggan akan sangat kecewa. Bila kinerja sesuai harapan, maka pelanggan akan merasa puas, sedangkan bila kinerja melebihi harapan, pelanggan akan sangat puas. Kepuasan pelanggan berarti bahwa kinerja suatu barang sekurang-kurangnya sama dengan apa yang diharapkan. Westbrook dan Reilly (Tjiptono, 2015) mengemukakan bahwa kepuasan merupakan respon emosional konsumen terhadap pengalaman yang berkaitan dengan produk dan jasa 
yang dibeli.

Tingkat kepuasan adalah fungsi dari perbedaan antara kinerja yang dirasakan dengan harapan. (Kotler, 2008). Jadi, tingkat kepuasan adalah sebagaimana yang dirasakan oleh setiap orang yang berbeda yang dirasakan dengan harapan yang sama. Kepuasan pelanggan adalah penilaian pelanggan terhadap produk atau pelayanan yang diberikan tingkat kenikmatan seperti yang diharapkan. Secara umum, prinsip kepuasan berpengaruh juga terhadap pelanggan sudah merasa puas dengan yang diberikan atau belum jika pelanggan sudah merasa puas berarti harapan baik, jaminan sudah sesuai dengan yang diberikan, karyawan mendengarkan kemauan pelanggan, pemimpin perusahaan dapat menjadi teladan dalam menjalankan tugasnya. Kepuasan pelanggan ditentukan oleh penilaian pelanggan terhadap produk atau jasa dalam memenuhi harapannya. Pelanggan merasa puas bila harapannya terpenuhi atau terlampaui.

Menurut Mardiyatmo (2008) faktor yang mempengaruhi tingkat kepuasan pelanggan ada lima, yaitu sebagai berikut: 1). Kualitas produk adalah pembeli akan puas bila membeli dan menggunakan produk yang memiliki kualitas baik. Misal, pelanggan akan puas terhadap sepatu yang dibeli sepatu tersebut enak atau nyaman dipakai, awet atau tidak cepat rusak, aman, dan desainnya menawan. 2). Harga adalah komponen sangat penting untuk memberi sumbangan terhadap kepuasan pelanggan. Produk yang berkualitas ditunjang dengan harga yang terjangkau akan menjadi sumber kepuasan yang penting. 3). Kualitas pelayanan adalah di tengah persaingan yang sangat ketat, banyak perusahaan yang lebih mengandalkan kualitas pelayanan. Karena kepuasan terhadap kualitas pelayanan biasanya sulit ditiru, sehingga bisa menjadi andalan dan keunggulan suatu perusahaan. 4). Faktor emosional adalah rasa bangga, percaya diri, simbol sukses adalah contoh - contoh emotional value yang mendasari kepuasan pelanggan. Faktor ini ditujukan untuk pelanggan yang menggunakan beberapa produk yang berhubungan dengan gaya hidup seperti, mobil, aksesoris, kosmetik, dan busana. 5). Faktor kemudahan adalah pelanggan akan semakin puas apabila dalam mendapatkan produk atau pelayanan relatif mudah, nyaman, dan efisien terhindar dari antrian yang panjang dan melelahkan.

Secara umum, pelanggan yang merasa puas dengan pelayanan yang diberikan kepada perusahaan atau koperasi dapat mempengaruhi prinsip kepuasan pelanggan karena harapan yang diinginkan pelanggan sesuai keinginan, menjamin produk yang dibeli pelanggan sesuai dengan harga pasar, mau mendengarkan suara pelanggan apa yang diinginkan sesuai dengan produk yang diharapkan. Tidak hanya prinsip kepuasan pelanggan tapi juga faktor yang mempengaruhi seperti harga, kualitas produk, kualitas pelayanan, dan faktor kemudahan. Dari uraian di atas dapat disimpulkan bahwa kepuasan anggota adalah suatu keadaan dimana harapan anggota terhadap suatu produk atau jasa koperasi sesuai dengan kenyataan yang diterima.

Menurut Rangkuti (2011) metode pengukuran kepuasan pelanggan yang dilakukan adalah dengan menggunakan metode survey. Pengukurannya dilakukan dengan cara sebagai berikut: 1). Pengukuran dapat dilakukan secara langsung melalui pertanyaan kepada pelanggan dengan ungkapan sangat tidak puas, kurang puas, puas dan sangat puas. 2). Responden diberi pertanyaan mengenai seberapa besar mereka mengharapkan suatu atribut tertentu dan seberapa pantas yang mereka rasakan. 3). Responden diminta menuliskan masalah-masalah yang mereka hadapi yang berkaitan dengan penawaran dari perusahaan dan diminta untuk menuliskan perbaikan - perbaikan yang mereka sarankan. 4). Responden diminta meranking elemen atau atribut penawaran berdasarkan derajat kepentingan setiap elemen dan seberapa baik kinerja perusahaan pada masing-masing elemen. 
Menurut Tjiptono (2015) indikator dari kepuasan adalah sebagai berikut: 1). "Kepuasan pelanggan secara keseluruhan; Pelanggan ditanya langsung seberapa puas mereka terhadap produk atau jasa yang diberikan perusahaan. 2). Konfirmasi harapan; Meliputi tingkat kesesuaian antara kinerja karyawan dengan harapan pelanggan. 3). Minat pembelian ulang; Pelanggan ditanya apakah akan membeli produk atau menggunakan jasa perusahaan lagi. 4). Kesediaan pelanggan untuk merekomendasikan; Jika pelanggan puas maka mereka akan merekomendasikan teman atau keluarga untuk menggunakan jasa perusahaan.

\section{Citra Perusahaan}

"Citra (image) merupakan seperangkat keyakinan, ide, dan pesan yang dimiliki seseorang terhadap suatu objek". (Kotler, dalam Sutisna, 2012). Kotler (2008), "citra (image) adalah kepercayaan, ide, dan impresi seseorang terhadap sesuatu". Bagi sebuah perusahaan, citra yang baik mutlak diperlukan. Sedemikian penting arti dari citra itu sendiri sehingga perusahaan bersedia mengeluarkan biaya dan tenaga ekstra untuk meraihnya. Citra adalah tujuan utama sekaligus merupakan reputasi dan prestasi yang hendak dicapai public relations. Jefkins (dalam dan Ardianto, 2010) citra adalah "kesan yang diperoleh berdasarkan pengetahuan dan pengertian seseorang tentang fakta - fakta atau kenyataan". Jadi citra terbentuk dari pengetahuan dan informasi-informasi yang diterima seseorang. Citra adalah "cara bagaimana pihak lain memandang sebuah perusahaan, seseorang, suatu komite atau suatu aktivitas". (Soemirat dan Ardianto, 2010). Citra merupakan "persepsi masyarakat terhadap perusahaan dan produknya, dan dipengaruhi oleh banyak faktor di luar kontrol perusahaan”. (Kotler 2008). Citra adalah realita, oleh karena itu jika komunikasi pasar tidak cocok dengan realita, secara normal realita akan menang. Citra akhirnya akan menjadi baik, ketika konsumen mempunyai pengalaman yang cukup dengan realita baru. Realita baru yang dimaksud yaitu bahwa sebenarnya organisasi bekerja lebih efektif dan mempunyai kinerja yang baik. Citra yang dibentuk harus jelas dan memiliki keunggulan bila dibandingkan dengan pesaingnya. Dari uraian di atas dapat disimpulkan bahwa citra koperasi adalah kesan anggota terhadap koperasi yang diperoleh melalui persepsi anggota tentang fakta - fakta atau kenyataan yang ada pada koperasi tersebut.

Menurut Anggoro (2001) mengemukakan ada beberapa jenis citra, antara lain: 1). Citra bayangan, yakni citra yang dianut oleh orang dalam anggota organisasi, biasanya adalah pemimpinnya mengenai anggapan pihak luar terhadap organisasinya, citra ini cenderung positif. 2). Citra yang berlaku, pandangan yang melekat pada pihak luar mengenai suatu organisasi. Citra ditentukan oleh banyak sedikitnya informasi yang dimiliki oleh penganut mereka yang mempercayai. 3). Citra harapan, yaitu citra yang diharapkan oleh pihak manajemen, biasanya dirumuskan dan diperjuangkan untuk menyambut sesuatu yang relatif baru, yaitu ketika khalayak belum memiliki informasi yang memadai. 4). Citra perusahaan, yaitu citra dari suatu organisasi secara keseluruhan, jadi bukan citra atas produk dan pelayanannya saja. Hal-hal positif yang dapat meningkatkan citra perusahaan adalah sejarah atau riwayat hidup perusahaan yang gemilang, keberhasilan-keberhasilan di bidang keuangan yang pernah diraih, sukses ekspor, hubungan industri yang baik, reputasi sebagai pencipta lapangan kerja yang besar, kesediaan turut memikul tanggung jawab sosial, komitmen mengadakan riset,dan sebagainya. 5). Citra majemuk, yaitu citra yang terbentuk dari masing - masing unit dan individu (pegawai atau anggota) dan citra yang terbentuk belum tentu sama dengan citra organisasi atau perusahaan atau organisasinya. 
Manfaat citra yang baik antara lain (Irawan, et al, 2008): 1). Dapat menarik sumber daya manusia manusia yang berkualitas untuk bergabung sehingga memiliki daya saing yang tinggi. 2). Dapat memperoleh kesempatan bisnis yang jauh lebih besar dari perusahaan dengan citra yang buruk. 3). Persentase kesuksesan produk atau layanan baru yang di luncurkan dapat jauh lebih tinggi di bandingkan dengan perusahaan dengan citra di bawah rata-rata industri. 4). Program dan aktivitas pemasaran juga menjadi lebih efisien. 5). Para investor akan lebih percaya dan akhirnya akan berpengaruh terhadap harga saham terutama bagi perusahaan yang sudah go public. 6). Loyalitas pelanggan akan meningkat dan mereka relative tidak sensitif terhadap harga. 7). Perusahaan menikmati pertumbuhan pendapatan dan laba yang lebih baik.

Fortune dalam Handi (2003) melakukan penelitian tentang citra dengan membatasi pada 4 (empat) indikator, yaitu: 1). Tanggung jawab sosial; adalah perilaku yang merupakan reaksi terhadap norma-norma, nilai-nilai dan harapan-harapan yang diselenggarakan masyarakat yang berlaku. Tanggung jawab koperasi dapat juga dikatakan sebagai tanggung jawab koperasi kepada lingkungan ekstern koperasi, misalnya pada masyarakat sekitar koperasi. Koperasi memberikan kompensasi atas keberadaan koperasi tersebut. 2). Inovasi; ditujukan untuk meningkatkan daya saing koperasi memiliki tanggung jawab sosial pada masyarakat sekitar. Inovasi merupakan ciri utama dari koperasi memiliki tanggung jawab sosial pada masyarakat sekitar yang berkinerja tinggi. Keberhasilan inovasi dipengaruhi oleh kemampuan koperasi memiliki tanggung jawab sosial pada masyarakat sekitar untuk menyerap dan mengevaluasi informasi lingkungan eksternal dan mengimplementasikan dalam kemampuan teknis Koperasi memiliki tanggung jawab sosial pada masyarakat sekitar. 3). Kualitas manajemen; Suatu manajemen yang baik harus dapat membuat keputusan yang tepat untuk koperasi memiliki tanggung jawab sosial pada masyarakat sekitar keputusan yang diambil akan berpengaruh terhadap kinerja koperasi dimata masyarakat. Manajemen yang berkualitas dari suatu koperasi adalah suatu manajemen yang dapat menerapkan fungsi-fungsi manajemen yang baik. 4). Kepercayaan masyarakat; yaitu persepsi masyarakat dengan koperasi tersebut. Kepercayaan masyarakat ini terbentuk setelah melihat kinerja dari koperasi sehingga masyarakat meyakini koperasi akan dapat memenuhi kebutuhan yang diinginkan masyarakat.

\section{Kualitas Layanan}

Kualitas layanan merupakan suatu pernyataan tentang sikap, hubungan yang dihasilkan dari perbandingan antara ekspektasi (harapan) dengan kinerja”. (Usmara, 2003). Definisi lain kualitas layanan adalah "upaya pemenuhan kebutuhan dan keinginan nasabah serta ketepatan penyampaiannya untuk mengimbangi harapan nasabah. (Tjiptono, 2015). Menurut Tjiptono (2015), kualitas layanan terdiri dari tingkat keunggulan yang diharapkan dan pengendalian atas tingkat keunggulan tersebut untuk memenuhi keinginan nasabah. Dengan kata lain ada "dua faktor utama mempengaruhi kualitas jasa, yaitu expected service dan perceived service atau kualitas jasa yang diharapkan dan kualitas jasa yang diterima atau dirasakan. Apabila jasa yang diterima atau dirasakan sesuai dengan yang diharapkan, maka kualitas jasa dipersepsikan baik dan memuaskan. Jika jasa yang diterima atau dirasakan melampaui harapan nasabah, maka kualitas jasa dipersepsikan sebagai kualitas yang ideal. Sebaliknya jika jasa yang diterima lebih rendah daripada yang diharapkan maka kualitas jasa dipersepsikan sebagai kualitas yang buruk.

Berdasarkan uraian uraian dapat disimpulkan kualitas layanan adalah kualitas tingkat layanan yang diberikan kepada anggota dari koperasi. 
Dalam hal ini kualitas layanan hendaknya dilihat dari sudut pandang anggota, anggotalah yang menentukan nilai kualitas. Parasunarman at al, dalam Joesron (2005) menyatakan menyatakan bahwa terdapat lima indikator kualitas layanan (servequal), yakni sebagai berikut: 1). Tangiable (keberwujudan fisik) meliputi sarana fisik seperti bangunan dan perlengkapan, penampilan karyawan, sarana komunikasi dan keberwujudan fisik lainnya yang dapat menjadi perhatian pelanggan. 2). Reliability (keandalan) merupakan kemampuan yang dapat diandalkan dalam memberikan jasa secara cepat, tepat, akurat dan konsisten sehingga dapat memuaskan anggota sebagai pelanggan. 3). Responsiveness (daya tangkap) adalah keinginan pribadi para staf dan karyawan perusahaan yang secara sadar ingin membantu pelanggan dan memberikan jasa sesegera mungkin sehingga dapat memuaskan pelanggan. 4). Assurance (jaminan) mencangkup pengetahuan, kemampuan dan keterampilan, kesopanan dan sifat dapat dipercaya yang dimiliki para staf dan karyawan sehingga menjamin pelanggan terhindar dari bahaya, resiko, atau keragu raguan dan kekecewaan. 5). Emphaty (empati) yang mencakup perhatian individu/pribadi dalam memahami kebutuhan pelanggan, kemudahan melakukan hubungan, komunikasi yang baik dan mudah dipahami.

Dalam proses layanan terdapat faktor penting dan setiap faktor mempunyai peranan yang berbeda-beda tetapi saling berpengaruh dan secara bersama akan mewujudkan pelaksanaan layanan yang baik. Moenir (2010) berpendapat bahwa ada enam faktor pendukung layanan, antara lain: 1). Faktor kesadaran adalah faktor yang mengarahkan pada keadaan jiwa seseorang yang merupakan titik temu dari berbagai pertimbangan sehingga diperoleh suatu keyakinan, ketetapan hati, dan keseimbangan jiwa. Dengan kesadaran akan membawa seseorang kepada kesungguhan dalam melaksanakan pekerjaan. 2). Faktor aturan adalah faktor perangkat penting dalam tindakan dan perbuatan seseorang. Oleh karena itu, secara langsung atau tidak langsung akan berpengaruh dengan adanya aturan ini seseorang akan mempunyai pertimbangan dan menentukan langkah selanjutnya. Pertimbangan pertama merupakan sebagai subyek aturan ditunjukkan oleh hal-hal penting. Kewenangan, pengetahuan dan pengalaman, kemampuan bahasa, pemahaman pelaksanaan, disiplin dan melaksanakan aturan, dan disiplin waktu dan disiplin kerja. 3). Faktor organisasi adalah faktor yang tidak hanya terdiri dari susunan organisasi tetapi lebih banyak pada pengaturan mekanisme kerja. Sehingga dalam organisasi perlu adanya sarana pendukung yaitu sistem, prosedur, dan metode untuk memperlancar mekanisme kerja. 4). Faktor pendapatan adalah pendapatan yang diterima oleh seseorang merupakan imbalan atas tenaga dan pikiran yang telah dicurahkan orang lain. Pendapatan ini dalam berbentuk uang, aturan atau fasilitas dalam waktu tertentu. 5). Faktor kemampuan adalah kemampuan yang diukur untuk mengetahui sejauh mana pegawai dapat melakukan pekerjaan sehingga menghasilkan barang atau jasa sesuai apa yang diharapkan. 6). Faktor sarana layanan adalah segala jenis peralatan, perlengkapan, dan fasilitas yang berfungsi sebagai alat pendukung utama dalam mempercepat pelaksanaan penyelesaian pekerjaan". Ada fungsi sarana layanan, antara lain: a). Mempercepat proses pelaksanaan pekerjaan sehingga dapat menghemat waktu. b). Meningkatkan produktivitas baik barang atau jasa. c). Ketetapan sarana yang baik dan terjamin. d). Menimbulkan rasa nyaman bagi orang yang berkepentingan. e). Menimbulkan perasaan puas pada orang-orang yang bekerja sehingga dapat mengurangi sifat emosional.

\section{METODE PENELITIAN}

Tujuan penelitian ini adalah untuk menganalisis hubungan kausalitas antara citra perusahaan dan kualitas layanan dengan kepuasan anggota. Data yang digunakan adalah 
data primer dengan menyebar kuesioner kepada anggota Kospin Jasa di Jakarta. Metode analisis data yang digunakan dalam penelitian ini adalah analisis deskriptif, analisis regresi linear sederhana dan berganda.

Sumber data adalah data primer yang diperoleh langsung dilapangan oleh orang yang melakukan penelitian. Data ini berisikan jawaban atas angket (pernyataan) yang disebarkan kepada seluruh responden. Populasi dalam penelitian ini adalah anggota Kospin Jasa Jakarta sebanyak 116 anggota. Dengan menggunkan rumus Slovin (Umar, 2013), diperoleh sampel sebanyak 55 responden, teknik yang digunakan untuk penarikan sampel adalah simple random sampling, pengambilan anggota sampel dari populasi dilakukan secara acak tanpa memperhatikan strata yang ada dalam populasi.

\section{HASIL PENELITIAN DAN PEMBAHASAN}

\section{Hasil Penelitian}

\section{Uji instrumen data}

Berdasarkan uraian tersebut, maka untuk dapat menentukan apakah variabel citra perusahaan dan kualitas layanan dapat dijadikan pengukur terhadap kepuasan anggota Kospin Jasa. Namun sebelumnya data diolah terlebih dahulu dan dilakukan pengujian terhadap varibel yang digunakan yaitu citra perusahaan, kualitas layanan dan kepuasan anggota untuk mengetahui apakah data tersebut akurat dan dapat dipercaya.

\section{Uji validitas}

Pengujian validitas ini dilakukan untuk menguji apakah tiap butir pernyataan telah mewakili indikator yang akan diteliti, persyaratan minimum untuk dapat dikatakan valid adalah $\mathrm{r}=0,30$. Jadi, apabila korelasi antara butir-butir item pernyataan dengan skor total kurang dari 0,30, maka butiran dalam instrumen tersebut dapat dikatakan tidak valid. Uji validitas dilakukan dengan melihat korelasi antara skor masing-masing item pernyataan dengan skor total.

\section{Uji Validitas Instrumen Variabel}

Dari perhitungan koefisien korelasi skor tiap butir pernyataan dari 55 responden tentang instrument citra perusahaan, dengan jumlah 8 pernyataan; instrumen kualits layanan 10 pernyataan dan instrumen kepuasan anggota 8 pernyataan dengan total skor setiap responden diperoleh hasil bahwa dari semua butir pernyataan variabel citra perusahaan, kualitas layanan dan kepuasan anggota hasilnya adalah valid.

\section{Uji reliabilitas}

Dari hasil pengujian reliabilitas berikut diketahui bahwa semua variabel mempunyai alpha di atas 0.60, yang berarti bahwa semua variabel dalam penelitian ini dapat diandalkan.

Tabel 1: Hasil Uji Reliabilitas Variabel

\begin{tabular}{lcc}
\hline \multicolumn{1}{c}{ Variabel } & Cronbach's Alpha & Keterangan \\
\hline Citra Perusahaan & 0.621 & Reliabel \\
Kualitas Layanan & 0.774 & Reliabel \\
Kepuasan Anggota & 0.698 & Reliabel \\
\hline \multicolumn{2}{l}{ Sumber: Hasil pengolahan data, 2020} &
\end{tabular}


Berdasarkan Tabel 1, angka-angka reliabilitas cronbach alpha tersebut tampak bahwa seluruh pernyataan yang ada membentuk ukuran yang reliable, yaitu citra perusahaan, kualitas layanan, dan kepuasan anggota.

\section{Analisis regresi linear sederhana}

Tabel 2: Pengaruh Citra Perusahaan Terhadap Kepuasan Anggota

\begin{tabular}{lccccc}
\hline \multirow{2}{*}{ Variabel } & $\mathbf{R}^{\mathbf{2}}$ & $\begin{array}{c}\text { Kons } \\
\text { tanta }\end{array}$ & $\begin{array}{c}\text { Koefisien } \\
\text { Regresi }\end{array}$ & Sig & $\boldsymbol{\alpha}$ \\
\hline Citra Perusahaan & 0,644 & 2,220 & 0,959 & 0,000 & 0,05 \\
\hline Pengujian Signifikan & & & & \\
\hline t hitung > t tabel = 9,791 > 2,006 & & & \\
\hline $\begin{array}{l}\text { Keterangan: Variabel Kepuasan Anggota } \\
\text { Sumber : data diolah 2020 }\end{array}$ & & & & \\
\end{tabular}

Berdasarkan Tabel 2, nilai koefisien determinasi $\left(\mathrm{R}^{2}\right)$ sebesar 0.644 , artinya citra perusahaan memberikan kontribusi sebesar 64,4\% kepada kepuasan anggota Kospin Jasa, sedangkan sisanya sebesar 35,6\% disumbangkan faktor lain yang tidak diteliti, seperti kualitas layanan.

$$
\text { Persamaan Regresi } \mathrm{Y}=2,220+0,959\left(\mathrm{X}_{1}\right)
$$

Citra perusahaan berpengaruh positif dan signifikan pada tingkat nyata $99 \%$ terhadap kepuasan anggota Kospin Jasa. Koefisien citra perusahaan sebesar 0,959, artinya jika ada peningkatan citra perusahaan satu kali, maka kepuasan anggota Kospin Jasa akan meningkat sebesar 0,959 kali atau sebaliknya.

Tabel 3: Pengaruh Kualitas Layanan Terhadap Kepuasan Anggota

\begin{tabular}{lccccc}
\hline \multirow{2}{*}{ Variabel } & $\mathbf{R}^{\mathbf{2}}$ & $\begin{array}{c}\text { Kons } \\
\text { tanta }\end{array}$ & $\begin{array}{c}\text { Koefisien } \\
\text { Regresi }\end{array}$ & Sig & $\boldsymbol{\alpha}$ \\
\cline { 2 - 6 } $\begin{array}{l}\text { Kualitas } \\
\text { Layanan }\end{array}$ & 0,652 & 8,707 & 0,627 & 0,000 & 0.05 \\
\hline Pengujian Signifikan & & & & & \\
\hline t hitung > t tabel = 9,954 > 2,006 & & & \\
\hline $\begin{array}{l}\text { Keterangan: Variabel Kepuasan Anggota } \\
\text { Sumber : data diolah 2020 }\end{array}$
\end{tabular}

Berdasarkan Tabel 3, nilai koefisien determinasi $\left(\mathrm{R}^{2}\right)$ sebesar 0.652 , artinya kualitas layanan memberikan kontribusi sebesar 65,2\% kepada kepuasan anggota Kospin Jasa, sedangkan sisanya sebesar 34,8\% disumbangkan faktor lain yang tidak diteliti, seperti citra perusahaan.

$$
\text { Persamaan Regresi } \mathrm{Y}=8,707+0,627\left(\mathrm{X}_{2}\right)
$$


Kualitas layanan berpengaruh positif dan signifikan pada tingkat nyata 99\% terhadap kepuasan anggota Kospin Jasa. Koefisien kualitas layanan sebesar 0,627, artinya jika ada peningkatan kualitas layanan satu kali, maka kepuasan anggota Kospin Jasa akan meningkat sebesar 0,627 kali atau sebaliknya.

Tabel 4: Pengaruh Citra Perusahaan dan Kualitas Layanan Terhadap Kepuasan Anggota

\begin{tabular}{lcccc}
\hline & \multicolumn{4}{c}{ Parameter } \\
\cline { 2 - 5 } \multicolumn{1}{c}{ Variabel } & $\mathbf{R}^{\mathbf{2}}$ & Konstanta & $\begin{array}{c}\text { Koefisien } \\
\text { Regresi }\end{array}$ & Sig. \\
\hline $\begin{array}{l}\text { Citra Perusahaan } \\
\text { Kualitas Layanan }\end{array}$ & 0,776 & 0,040 & $\begin{array}{r}0,568 \\
0,380\end{array}$ & 0,000 \\
\hline Pengujian Signifikan & & & \\
\hline F hitung > F tabel = 90,163 > 3,175 & & \\
\hline Keterangan: Variabel Kepuasan Anggota \\
Sumber: data diolah 2020
\end{tabular}

Berdasarkan Tabel 4, nilai F hitung lebih besar F tabel $(90,163>3,175)$, maka Ho tolak, Ha terima, artinya ada pengaruh yang positif dan signifikan citra perusahaan dan kualitas layanan terhadap kepuasan anggota Kospin Jasa. Nilai koefisien determinasi $\left(\mathrm{R}^{2}\right)$ sebesar 0.776, artinya citra perusahaan dan kualitas layanan secara bersama-sama memberikan kontribusi sebesar 77,6\% kepada kepuasan anggota Kospin Jasa, sedangkan sisanya sebesar $22,4 \%$ disumbangkan faktor lain yang tidak dibahas dalam penelitian ini.

$$
\text { Persamaan Regresi } \mathrm{Y}=0,040+0,568\left(\mathrm{X}_{1}\right)+0,380\left(\mathrm{X}_{2}\right)
$$

Citra perusahaan dan kualitas layanan berpengaruh positif dan signifikan terhadap kepuasan anggota Kospin Jasa pada tingkat nyata 99\%. Koefisien citra perusahaan sebesar 0,568, artinya jika ada peningkatan citra perusahaan satu kali, maka kepuasan anggota Kospin Jasa akan meningkat sebesar 0,568 kali atau sebaliknya dengan asumsi kualitas layanan tidak berubah. Koefisien kualitas layanan sebesar 0,380, artinya jika ada peningkatan kualitas layanan satu kali, maka kepuasan anggota Kospin Jasa, akan meningkat sebesar 0,380 kali atau sebaliknya, dengan asumsi citra perusahaan tidak berubah.

\section{Pembahasan}

\section{Pengaruh Citra Perusahaan Terhadap Kepuasan Anggota Kospin Jasa}

Hasil penelitian ini menunjukkan bahwa citra perusahaan yang baik akan dapat mendorong peningkatan kepuasan anggota. Hal ini dikarenakan bahwa perusahaan memiliki tanggung jawab sosial pada masyarakat sekitar, memberikan bantuan terhadap lingkungan, mengembangkan daya saing koperasi, menyerap informasi eksternal, manajemen membuat keputusan yang tepat, dan menerapkan fungsi-fungsinya, pandangan masyarakat terhadap koperasi positif, dan kinerja koperasi dapat meyakinkan masyarakat. Hasil penelitian ini sesuai dengan penelitian yang dilakukan oleh Susiyanti, et al, (2017) dan Kusdayanti, (2016), yaitu menganalisis pengaruh citra koperasi terhadap kepuasan anggota koperasi. 


\section{Pengaruh Kualitas Layanan Terhadap Kepuasan Anggota Kospin Jasa}

Hasil penelitian ini menunjukkan bahwa kualitas layanan dapat mendorong peningkatan kepuasan anggota. Hal ini dikarenakan bahwa ruangan koperasi dikelola dengan rapih, karyawan berpenampilan ramah, memberikan layanan dengan cepat dan cepat tanggap sehingga anggota merasa puas, membantu para anggota yang kesulitan, kemampuan karyawan dapat dipercaya, memiliki pengetahuan dapat diandalkan, koperasi memahami kebutuhan anggota, pengurus melakukan hubungan komunikasi dengan baik pada anggota. Hasil penelitian ini sejalan dengan penelitian yang dilakukan oleh Ikhsan, (2018) dan Dharmawati, et al, (2018), yaitu menganalisis pengaruh kualitas pelayanan terhadap kepuasan anggota koperasi.

\section{Pengaruh Citra Perusahaan dan Kualitas Layanan Terhadap Kepuasan Anggota Kospin Jasa}

Berdasarkan hasil analisis diketahui bahwa citra perusahaan dan kualitas layanan mendorong peningkatan kepuasan anggota Kospin Jasa. Hasil penelitian ini sama dengan hasil penelitian yang dilakukan oleh Susiyanti, et al, (2017) dan Kusdayanti, (2016), dan Marna, et al, (2014), yaitu menganalisis pengaruh kompensasi dan disiplin kerja terhadap kepuasan kerja karyawan.

\section{KESIMPULAN DAN SARAN}

\section{Kesimpulan}

1). Citra perusahaan mendorong peningkatan kepuasan anggota Kospin Jasa. 2). Kualitas layanan mendorong peningkatan kepuasan anggota Kospin Jasa. 3). Citra perusahaan dan kualitas layanan mendorong peningkatan kepuasan anggota Kospin Jasa.

\section{Saran}

1. Terus lakukan berbagai upaya untuk meningkatkan citra perusahaan pada Kospin Jasa, melalui fasilitas yang dimiliki oleh Kospin Jasa.

2. Mengingat kontribusi yang terbesar dalam koperasi adalah kualitas layanan yang dapat mempengaruhi kepuasan anggota, maka hendaknya pengurus Kospin Jasa lebih meningkatkan pelayanan yang diberikan kepada anggotanya, seperti tempat yang memadai, memberikan jaminan dengan adanya pendeteksi keaslian uang, berikan layanan yang prima.

3. Bagi peneliti selanjutnya dapat menambah variabel lain yang dapat mempengaruhi kepuasan anggota koperasi, seperti kualitas produk dan promosi.

\section{DAFTAR PUSTAKA}

Anggoro, M.Linggar. 2001. Teori Profesi Kehumasan. Jakarta: Bumi Aksara.

Dharmawati, Erni dan Suryaningsih, Sri Abidah. 2018. Pengaruh Kualitas Pelayanan Terhadap Kepuasan Anggota KJKS KUM3 Rahmat Surabaya. Jurnal Ekonomi Islam Volume 1 Nomor 2, Tahun 2018. Hal. 45-54.

Handi, Irawan. 2003. Mengukur Citra Perusahaan. Yogyakarta: BPFE 
Hazlina dan Abdul Kadir 2011. Impact Of Service Quality On Customer Satisfaction : Study Of Online Banking And ATM Service In Malaysia. Vol.2 No.1. Internattional Journal Of Trade, Economics and Finance.

Husein, Umar. 2013. Metode Penelitian untuk Skripsi dan Tesis. Jakarta: Rajawali.

Ikhsan, Anwar. 2018. Pengaruh Kualitas Pelayanan Terhadap Kepuasan Anggota Koperasi Karyawan Universitas Mercu Buana Jakarta. Jurnal Ilmiah Manajemen Bisnis, Volume 4, No. 1, Maret 2018. Hal. 62-85.

Irawan, Basu Swasta, dan Dharmesta. 2008. Manajemen Pemasaran Modern. Yogyakarta: Liberty.

Istijanto, Oei. 2010. Riset Sumber Daya Manusia. Edisi Revisi Gramedia Pustaka Utama. Jefkins, Franks 2004. Public Relations. Jakarta: PT. Gelors Aksara Pertama Erlangga. Joesron. 2005. Manajemen Strategis Koperasi. Yogyakarta: Graha Ilmu.

Kotler, Philip. 2008. Marketing Management, Milenium Edition, Jersey : Pearson Custom Publishing.

Kusdayanti, Niken. 2016. Pengaruh Citra Koperasi dan Kualitas Pelayanan Terhadap Kepuasan Anggota Koperasi Pegawai Republik Indonesia Setia, Kec. Mojotengah, Kab. Wonosobo. Jurnal Pendidikan dan Ekonomi, Volume 5, Nomor 2, Tahun 2016. Hal. 124-131.

Mardiyatmo. 2008. Kewirausahaan untuk SMK Kelas XI. Jakarta: Yudistira

Marna, Jean Elikal dan Wardi, Yunia. 2014. Pengaruh Kualitas Pelayanan dan Citra Koperasi Terhadap Partisipasi Anggota Koperasi Plasma Sawit Bukit Sandiago Tigo Bawan Kab. Agam. Jurnal Kajian Pendidikan Ekonomi. Vol. 1, No. 1. 2014. Hal. 3643

Moenir, HAS 2010. Manajemen Pelayanan Umum di Indonesia. Jakarta: Bumi Aksara.

Oliver, Richard L. 1997. Whence Customer Loyalty. Journal of Marketing, Vol. 63 (Special Issues).

Parasuraman A,dan Berry, L. Leonard. 1991. A Marketing services. New york: The Free Press

Rangkuti, Freddy. 2011. Riset Pemasaran. Jakarta, PT. Gramedia Pustaka Utama.

Soemirat, Soleh dan Ardianto, Elvinaro. 2010. Dasar-Dasar Public Relations. Bandung: Remaja Rosdakarya.

Sugiyono. 2016. Statikstika Untuk Penelitian. Bandung. Penerbit Alfabeta.

Susiyanti dan Asim. 2017. Pengaruh Citra Koperasi dan Kualitas Pelayanan Terhadap Kepuasan Anggota Koperasi Karyawan Rumah Sakit Anak dan Bunda (RSAB) Harapan Kita Jakarta. Jurnal Administrasi dan Manajemen Vol. 10, No. 2, Desember 2017. ISSN: 1693-6876. Hal. 661-669

Sutisna. 2012. Perilaku Konsumen dan Komunikasi Pemasaran. Edisi Kedua. Bandung: Remaja Rosdakarya.

Tjiptono, Fandy. 2015. Strategi Pemasaran. Yogyakarta: Penerbit Andi.

Usmara, A .2003. Strategi Baru Manajemen Pemasaran. Yogyakarta: Amara Books.

Undang-Undang RI Nomor 25 Tahun 1992 Tentang Koperasi

Westbrook dan Reilly. 1983. Dalam Tjiptono, Fandy. 2005. Brand Management and Strategy. Yogyakarta: Penerbit Andi. 